\title{
SPECIAL AUTONOMY FUND TO REDUCE POVERTY: DOES IT WORK?
}

\author{
Ikhsan $^{1 *}$, Utang Suwaryo ${ }^{2}$, Neneng Yani Yuningsih ${ }^{3}$, Franciscus Van Ylst ${ }^{4}$ \\ ${ }^{1}$ Departmennt of Public Administrastion, Universitas Teuku Umar, Aceh, Indonesia; ${ }^{2,3,4}$ Department of Government \\ Science, Universitas Padjdjaran, Bandung, Indonesia. \\ Email: ${ }^{1 *}$ Ikhsan.baharudin@utu.ac.id, ${ }^{2}$ utang.suwaryo@ unpad.ac.id, ${ }^{3}$ neneng.yani@ unpad.ac.id, ${ }^{4}$ vanylst@ yahoo.com
} Article History: Received on $19^{\text {th }}$ March 2020, Revised on $14^{\text {th }}$ April 2020, Published on $19^{\text {th }}$ May 2020

\section{Abstract}

Purpose of the study: The aim of this study is to examine the role of special autonomy funds in poverty reduction in Aceh and to find out how to deal with poverty in Aceh and what obstacles are faced by Aceh Government.

Methodology: This research used a qualitative method with a case study approach to provide a detailed explanation and exploitation. Research data obtained through interviews and data obtained also through local and national online media and the media data were analyzed using Nvivo 12 Plus, specifically by using the NCapture feature, which allows researchers to systematically compile and analyze documents.

Main Findings: This study found that the implementation of poverty reduction programs and policies is still in the form of false participation due to low transparency and accountability and economic dependence on other regions outside Aceh and the small number of medium and large industries in Aceh.

Applications of this study: The findings of this study are useful for exploration by the Aceh Government in order to maximize the role of special autonomy funds in poverty alleviation efforts in Aceh.

Novelty/Originality of this study: Research on the Aceh Special Independence Fund has been widely explained by a number of researchers. However, there is no publication that specifically explains the role of special self-government funds to reduce poverty. Consequently, the use of accountable and transparent special autonomy funds can reduce poverty in Aceh.

\section{Keywords: Special Autonomy Fund, Poverty Reduction, Pro-poor Budgeting, Local Government. \\ INTRODUCTION}

Poverty is classified as a crucial issue to be discussed therefore many studies have been conducted on the causes of poverty. Poverty caused by a situation that is completely limited due to external factors and the result of human interaction also usually caused by dependence on external assistance thus a person not only deprived but also passive and isolated from his world (Amalia, 2015; Suparlan, 1984; Winardi, 2010). In addition, poverty is not only caused by economic and social problems in society but also caused by more than one dimension of poverty (Baharoglu, D \& Kessides, 2001; Harris, 2005; Kuncoro, 2002).

Indeed, the Indonesian Central Statistics Agency (BPS) (BPS, 2014, 2018) states that poverty is the inability to meet basic needs and is often also regarded as a very complex and multidimensional problem (Arsyad, 2014; Prayitno, 1987; Shepherd, 2017). Based on the aspect of general policy, poverty includes the primary aspects of being poor in assets, socio-political organizations, and knowledge and skills. While the secondary aspects of poor are a social network, financial resources and information which finally manifested in the form of malnutrition, water, healthy housing, poor health care and low levels of education. Once the multidimensional problem of poverty makes the definition of poverty obscure and multifaced. Economically, the poor population does not have anything (having nothing) socially they are not anyone (being nothing) and politically they do not get rights except victims of development (having no rights and being wrong) (Kwadzo, 2010; Swastika, Dewa KS., Supriyatna, 2008).

Ultimately, poverty has subjective and different definitions so that there is no exact definition of poverty (Alcock, 1997; Huraerah, 2013). The ambiguity of this definition of poverty is attempted to be simplified by many groups through the conventional definition of poverty, which is the inability to meet the basic needs of clothing, food, and shelter. And has not been able to improve the ability to meet secondary and tertiary needs such as the availability of access to education, health, and the market (Hadar, 2004). A person who is poor and not well-off is considered to have no income that is able to meet consumption, ownership of property, capital assets, and stock (Tarlton, 1965). However, Sen (1976) disagrees with the opinion that only uses economic welfare as a measure of poverty. The three measures of economic prosperity are income, consumption, and welfare which are further defined using absolute, relative, and subjective concepts. According to Sen (1976), the resulting measure is very limited because in this way of measuring economic welfare there are no restrictions for non-consumption goods such as recreation, social involvement and the state of human capital (Asmorowati and Marcus, 2006; Hagenaars, 1991; Wagle, 2002).

According to the United Nations, the poverty level in Indonesia since 2000 has decreased by more than half, but one in ten developing regions is still alive with an income of less than 1.90 USD per day. The internationally agreed poverty line is a little higher than 1.90 USD. Even so, East and Southeast Asia are in better condition than sub-Saharan Africa, where 42 percent of the population is poor or lives in poverty (Nation, 2008). As for Indonesia, in 2018 the average poverty percentage in Indonesia is 9.66 percent. As a developing country, poverty is a problem that has long been a 362 |www.hssr.in

(c) Ikhsan et al. 
problem of the Indonesian people (Agusta, 2014; Alfian, 1980; T. Arifin, 2006; Jonadi, 2002). The difference between poverty in developed and developing countries is in the way of measurement which further has implications for how policy interventions in poverty alleviation efforts (B. Arifin, 2006; Dartanto, 2013; Kamarni, 2012).

On the other hand, there are still many regions in Indonesia where the percentage of poverty is quite high such as Papua and Aceh. According to BPS data in 2017, Aceh's poor population is 16.89 percent and in 2018 is 15.97 percent, the decline is quite low when compared to the national poverty reduction target of 7-8 percent with a moderate target of 8-10 percent (Kemenkopmk, 2014). However, if it is associated with asymmetric fiscal decentralization which is owned by Aceh through the special autonomy fund, the reduction in the poverty rate has not been significant. One thing that is missing from poverty alleviation policy efforts in Aceh is the lack of consideration of aspects of actors who have the knowledge and ability to deal with poverty issues in Aceh (Okezone, 2018; Serambinews, 2018). Especially related to the characteristics of poor areas in rural areas in the form of dry land and flood subscriptions as well as the complexity of economic, social problems in the area.

Table 1: Percentage of the Poorest Population by Province

\begin{tabular}{llll}
\hline \multirow{2}{*}{ No } & Province & \multicolumn{2}{c}{ Percentage of Poverty } \\
\cline { 3 - 4 } & & 2018 & 2019 \\
\hline $\mathbf{1 .}$ & Papua & 27,43 & 27,53 \\
\hline $\mathbf{2 .}$ & Papua Barat & 22,66 & 22,17 \\
\hline $\mathbf{3 .}$ & Nusa Tenggara Timur & 21,03 & 21,09 \\
\hline $\mathbf{4 .}$ & Maluku & 17,85 & 17,69 \\
\hline $\mathbf{5 .}$ & Gorontalo & 15,83 & 15,52 \\
\hline $\mathbf{6 .}$ & Aceh & 15,68 & 15,32 \\
\hline
\end{tabular}

Source: BPS Data in 2019

This paper discusses the role of special autonomy funds in reducing poverty in Aceh. Special autonomy funds are funds sourced from the National Revenue and Expenditure Budget (APBN) allocated to the regions in the context of implementing decentralization. The fund consists of the Balancing Fund and the Special Autonomy and Adjustment Fund. The funds are given to the provinces by the Government of Indonesia along with the special authority that arises to regulate and manage the interests of the community in accordance with their own initiatives and in accordance with the aspirations and basic rights held by the people in the region. Aceh as one of the provinces that obtained special fiscal authority regulated in Law Number 11 of 2006 concerning the Government of Aceh through a special autonomy fund that is expected to be able to side with the poor (pro-poor budgeting).

\section{LITERATURE REVIEW}

\section{Concepts of Poor and Poverty}

Previous research on government budget allocations to poverty has been conducted by Ravallion and Datt (Ravallion, 2001); Fan (1998); Jung et al (2003); Agrawal (2005); and Hong and Ahmed (2009). To overcome various poverty problems in Aceh, the government began in 2008 to allocate a special autonomy fund to support the implementation of special autonomy regions properly. The types of programs and activities carried out through the special autonomy fund are budget allocations that favor the poor (pro poor budgeting) (Appleford, Gabrielle, 2015).

Ravallion and Datt (Ravallion, 2001) in their research found that government spending on development reduces poverty. Fan (Fan, 1998) government spending on education, roads, health, and welfare and rural development have an effect on reducing poverty levels. While Agrawal (Agrawal, 2005) says that government spending on the social sector is needed to reduce poverty. One of the social factors is backwardness, market imperfection, and lack of capital which causes low productivity so that the income received is also low. According to Nurkse in Kuncoro (Kuncoro, 2002), the existence of low income will have implications for low savings and investment, which then causes backwardness and the chain continues to repeat.

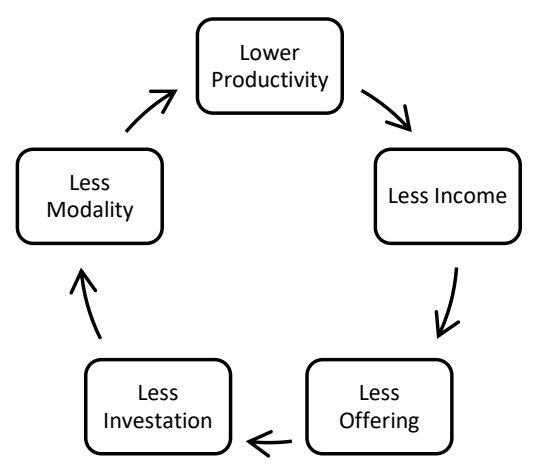

Figure 1: Vicious Circle of Poverty (Kuncoro, 2006) 
Talking about poverty, various efforts have been made by the government of a country and apparently not necessarily able to overcome poverty. Rahardjo (2006) said that the failure was caused by an error in defining the concept of poverty so that in the end the methodological implications of measuring poverty became biased and not on target, including when routine monitoring and evaluation were carried out. Poverty must be seen by a mixture of top-down and bottom-up perspective methods through the perspectives of practitioners and policymakers from the government and also those who experience poverty who are certainly more aware of exactly what poverty is. This needs to be done so that information, data and facts are not biased (Firdaussy, CM dan Tisdell, 1992; Ravallion, 2001; Siahaan, 2011).

\section{Pro-Poor Budget}

Budgeting is an arena of war between financial managers oriented to macroeconomic stability and planners as well as the poor. Budget managers tend to be anti-poverty and view that populist policies are something that threatens macroeconomic stability (Brautigam, 2004; Simson, 2012; Waidl, 2008). Talking about the Regional Budget Revenue and Expenditure (APBD) is not only related to administrative and managerial matters of public finance but also related to ideological and political affairs (Appleford, Gabrielle, 2015; Fan, 1998). In brief, one's ideological choice will be the direction in which the allocation, distribution and stabilization of public finances will be given. For example, the liberalcapitalist ideology will direct the reduction of the distribution function that has been carried out by the State at the same time leaving the allocation and stabilization functions to other parties, namely market (Collier, Paul and Dollar, 2002; Robinson, 2006; Sanogo, 2019). The market-oriented APBD model will also prioritize pro-market development if it must be confronted with community-based interests. Whereas political choice shows that the APBD is a result of the arena of power of the actors starting from actors from the regional legislative body, regional executive institutions, businessmen, community organizations and the poor. budget politics or pro-poor budgeting is a budget policy that has a concern for the poor (Grayman, Delvecchio, 2009; Samson, 2009; Schneider, 2009; Vandemoorele, 2003). Researching budget policy means that finding out whether the government has a concern for the poor in the poverty alleviation budget sector in Aceh (Yunus, S., Zainal, S., Jalil, F., \& Maya Aprita Sari, 2020).

Poverty reduction programs must be able to increase the capacity of local governments in community services, especially the poor, through policies, programs, and budgeting that are in favor of the interests of the poor (pro-poor policies) both in terms of the budget (APBD and APBN) and in terms of priorities (Hagenaars, 1991; Mundra, 2019; Roberts, 2003; Sen, 1976; Wagle, 2002). In this situation, the government takes good intentions on the side of the weak, such as having a role to play in controlling the distribution of budgets, goods and services, controlling the distribution of income and development services, and opening up equal opportunities for financial access (capital) to the disadvantaged (Agrawal, 2005; Dartanto, 2013; Firdaussy, CM dan Tisdell, 1992; Swastika, Dewa KS., Supriyatna, 2008).

Various development strategies that are oriented towards the interests of the poor (pro-poor policy) must be more nuanced and must pay attention to the heterogeneity of the causes of poverty in each region, not immediate and permanent and focused. On the other side, pro-poor budget policies in the center and regions converted into poverty alleviation initiatives must be pursued in order to provide transparency about the beneficiaries (who, where, as well as regular assessments of program success and effect indicators. In addition to being relevant in setting targets, the urgency of poverty reduction needs to be met by the government and the regions in the form of a quantitative (measurable) reduction of the poverty reduction target (Alcock, 1997; Amalia, 2015; Collier, Paul and Dollar, 2002; Kwadzo, 2010; Shepherd, 2017).

\section{METHODOLOGY}

This research was conducted in Aceh Province related to the use of special autonomy funds as an effort to reduce poverty. Increasing the amount of special autonomy budget every year from 2008 to 2019 is an effort to reduce poverty significantly. At least some of the special autonomy fund management authority schemes have been implemented in Aceh. The funds divided into 60 percent for the province and further 40 percent for the district, however, it is changed to the province 40 percent and district 60 percent. Recently, based on the rules, province 60 percent and district 40 percent. The focus of this study is to find out how to deal with poverty in Aceh and what obstacles are faced by the Aceh Government.

The method used in this paper is a qualitative case study approach (Craswell, 2014). Things explored included (1) how the use of regional autonomy funds for the benefit of poverty reduction so far in Aceh Province. (2) What factors are hampering the process of poverty reduction in Aceh from 2008 to 2019 which have an impact on the success and failure of various policy programs implemented by the Government of Aceh. To answer the question above, a qualitative approach is used to provide a detailed explanation and exploitation. Research data obtained through interviews with 10 participants included the Head of Aceh Bappeda, the poverty-management staff in Aceh Bappeda and the Community. and data obtained also through local and national online media such as waspadaaceh.com, Serambi Indonesia, rencongpost.com, kumparan.com, kompas.id, acehprov.go.id, aceHTrend.com, bappeda.acehprov.go .id. The media data were analyzed using Nvivo 12 Plus, specifically by using the NCapture feature, which allows researchers to systematically compile and analyze documents (Fallis, 2013). 


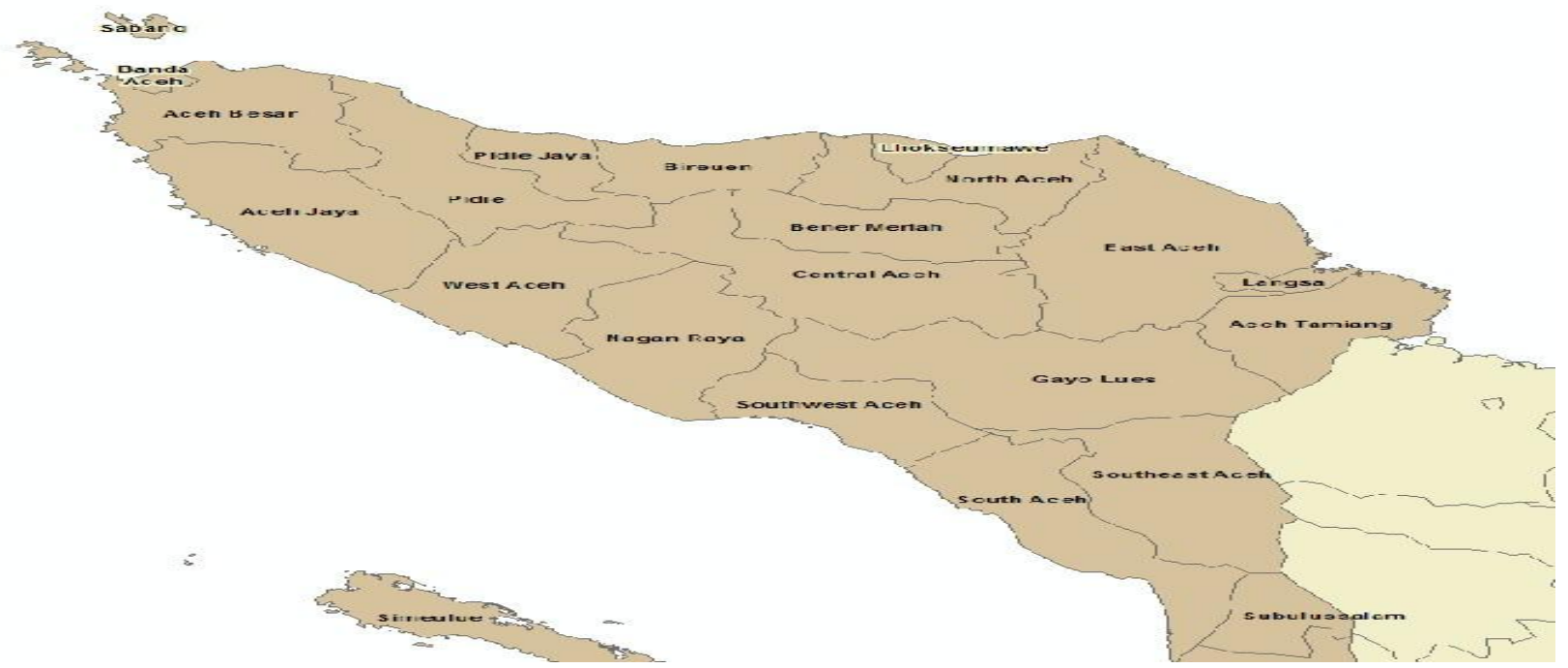

Figure 2: Borders of Aceh Province

\section{RESULTS/FINDINGS}

The allocation and distribution of special autonomy funds are not necessarily able to significantly reduce poverty in Aceh. Do many people disagree about whether the huge special autonomy fund has been effective in reducing poverty? Or in fact, Aceh still remains in poverty. The year 2020 was marked by viral online news and banners about Aceh which received the title of the poorest region while in an effort to reduce poverty in Aceh, the budget allocation provided for handling poverty continues to increase each year. If in 2008 received an allocation of Rp 120 billion and increased in 2019 to Rp 439 billion. The claim from the Government of Aceh is the addition of the special autonomy budget allocation shows the seriousness of the government on the problem of poverty.

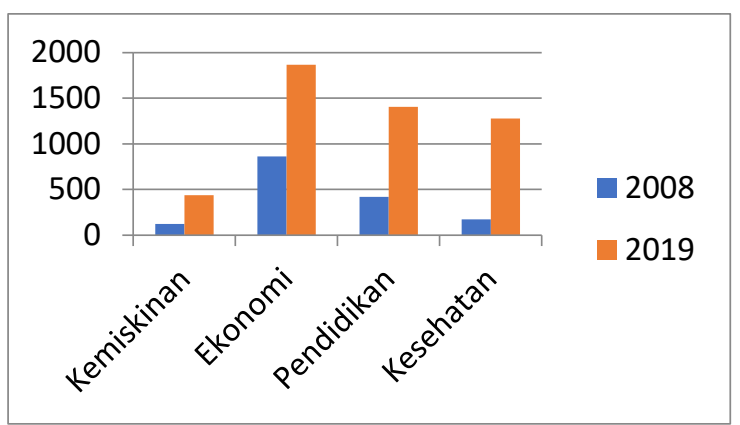

Figure 3: Special Autonomy Funds in 2008 and 2019 (Bappeda Aceh, 2019)

Based on the chart above, it can be seen that there has been a significant increase in the areas of poverty budget, economy, education, and health from 2008 to 2019. It implies from the details of budget allocations for economic empowerment, which initially received special autonomy funds in 2008 only around Rp. 860 billion, continues to grow and in 2019 it has reached Rp. 1,867 trillion. Likewise, the allocation for education from Rp 418 billion in 2008 increases to $\mathrm{Rp} 1.404$ trillion in 2019, and the health sector from Rp 171 billion increased to Rp 1.277 trillion.

The management of special autonomy funds is not fully carried out by the Government of Aceh, but there are joint programs and activities, and there are also allocators for provinces and districts/cities. The form of joint programs and activities between the provincial government and district/city government consists of implementing health insurance (JKA Program), student scholarships, education funding assistance for orphans, construction of livable homes, and other programs and activities determined by the Governor. Specifically, the division of districts/cities and provinces in 2019 is 60 percent of provinces and districts/cities 40 percent. Furthermore, the division of the allocation of special autonomy funds for districts/cities is divided into two with details, namely the basic allocation of 50 percent of the 40 percent quota and the remaining 50 percent divided according to the formula: the total population of 40 percent, area of 30 percent of women, Human Development Index (HDI) 20 percent, and Construction Expense Index (IKK) by 10 percent. The purpose of the Aceh Government is that the distribution of the special autonomy funds is to create a proportional and fiscal division of authority based on population, area and regional conditions thus there is no large gap between regions.

When reading various online news about Aceh poverty after the release of BPS data and the pros and cons of the community's reaction to the condition of Aceh, at least the various online requests that were subjected to observation and data processing that has been done using nvivo show that each online media has a different focus in reporting poverty in 
Aceh. The following illustration is related to the relationship between online reporting and the most used words in reporting.

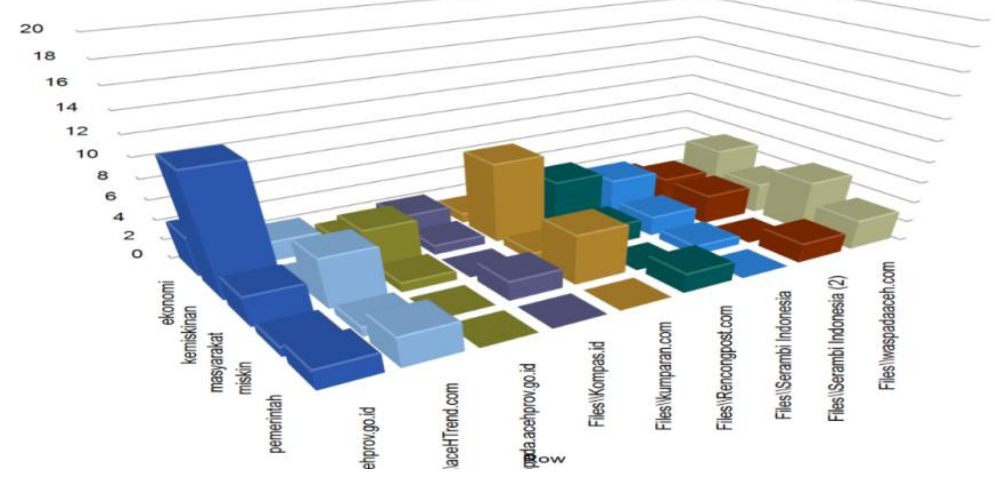

Figure 4: Pictures of Online Media Coverage About Poverty

According to the sentiment of the news that was built was neutral, namely Kompas.id, rencongpost.com, porch Indonesia, waspadaaceh.com, acehprov.go.id. Neutral coverage with a bit of positive coverage is shown by the kumparan.com news about poverty in Aceh. Whereas AceHTrend shows sentiment, neutral, positive, and negative at the same time. The illustration can be seen in the picture below with the color description of the image: gray (neutral), green (positive), and red (negative).

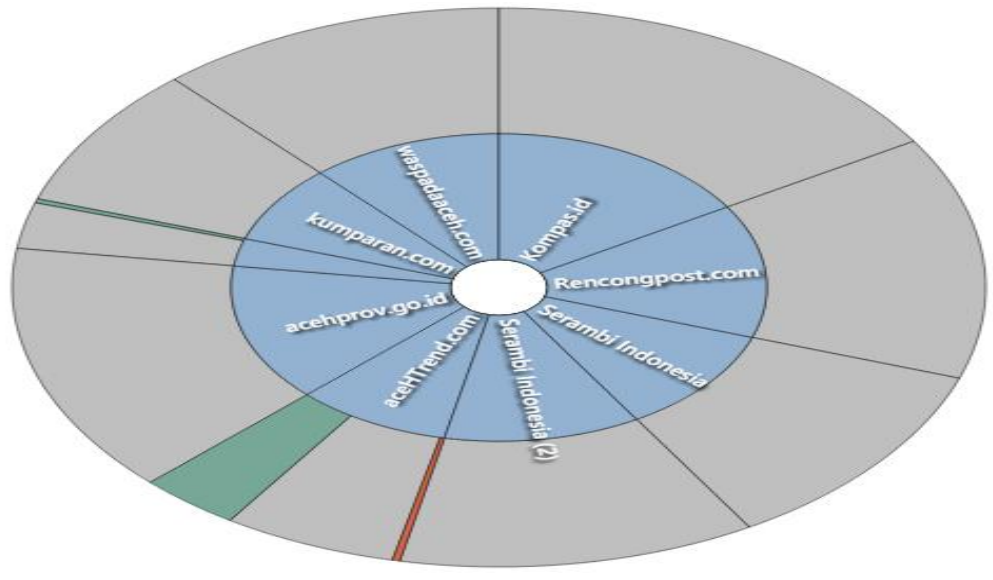

Figure 5: The Sentiment of Online Media Coverage on Poverty in Aceh

The obstacle of the slow decline in poverty is caused by the first, Aceh's economy is still very dependent on other regions. The explanation is that most of the needs of Acehnese people are still being supplied from outside of Aceh, therefore it is not surprising that there is a large deficit in the inter-regional trade balance of Aceh, which is around Rp 10-11 trillion in the last three years. In short, it can be said that the ability to sell products outside of Aceh is very slight compared to the ability to buy goods from outside of Aceh. This statement is reinforced by the fact that the data of the velocity of money in 2018 owned by Bank Indonesia Aceh is only Rp 3 trillion (2018). Finally, the multiplier effect of money circulation in Aceh is expected to not have a significant impact on economic growth, job creation, and poverty alleviation.

Aside from the dependency factor, the second obstacle is that there still a small number of medium and large industries in Aceh that also need attention. It is undeniable that the existence of industry is closely related to the availability of a lot of jobs, which in turn has an effect on poverty reduction in Aceh. In short, the more people who work, the lower the poverty rate in an area. The Aceh government is currently trying to encourage economic growth and reduce Aceh's poverty rate from 15.68 (2018) to 15.32 (2019). One effective poverty alleviation strategy is through the empowerment of MSMEs as the largest sector of absorbing labor, seen from the issuance of an appeal from the Acting Governor of Aceh for the use of local Acehnese products in various events and activities of SKPA or other agencies in Aceh and becoming one of the solutions to market access problems experienced by MSMEs so far. The development of MSMEs will have a positive impact on various aspects, namely job creation, poverty reduction, economic growth, even to the reduction of Indonesia's current account deficit (current account deficit) if MSME products are export-oriented or substitute for imported goods. The appeal of the Acting Governor of Aceh has been applied in every event and activity carried out by the regional government, the regency/city regional government will cooperate with IKM and UMKM. For 
example, as a food provider in the event or as a supporting tool for seminar and training activities in the form of a goodie bag for the activities.

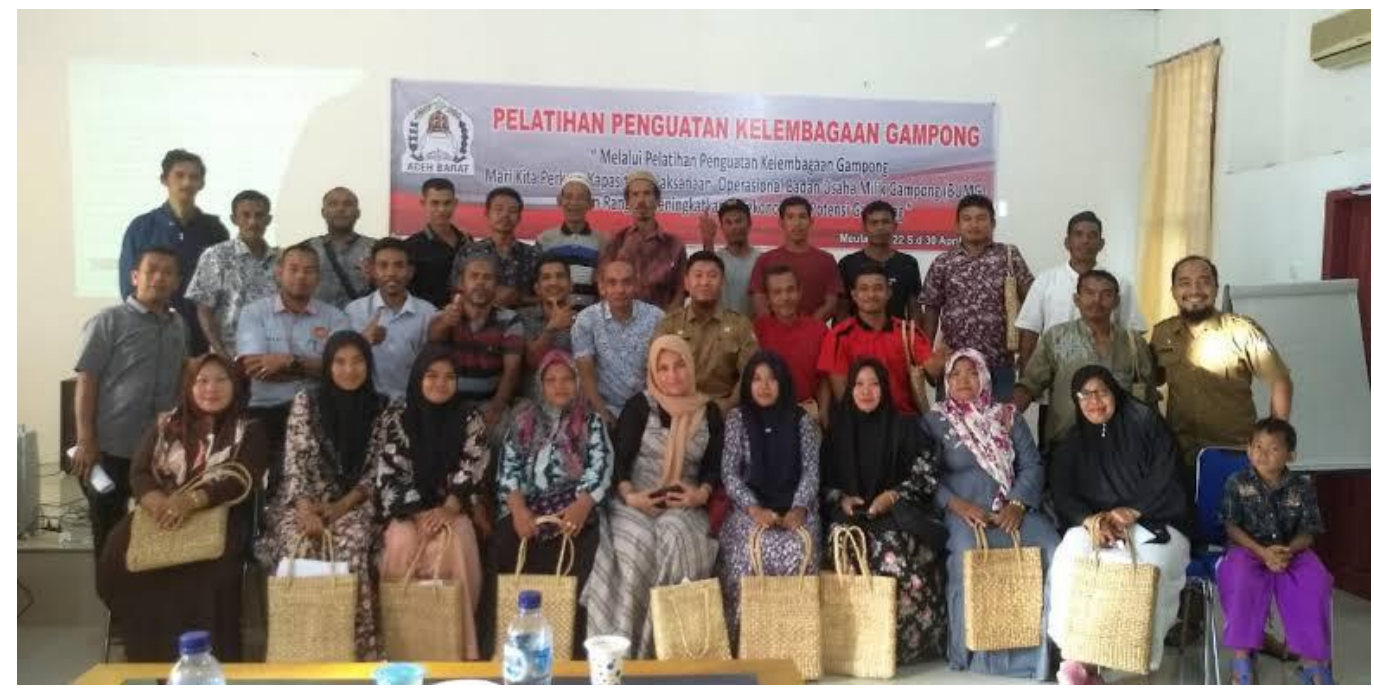

Figure 6: The Water Hyacinth Bag from IKM Crafts becomes a Goodie Bag for Training Activities in West Aceh

\section{DISCUSSION / ANALYSIS}

Poverty in Aceh is caused by the social dynamics and economic conditions that have occurred since the beginning of Indonesian independence. This condition was exacerbated by the efforts of the Aceh Province which had tried to separate itself from Indonesia repeatedly, starting from the separation effort in 1953 led by Daud Beureueh who was dissatisfied with the Soekarno government, especially related to the merger of the Aceh region under the North Sumatra Residency (El Ibrahimy, 2001). So then in 1959 President Soekarno granted Aceh first autonomy in the fields of religion, education and customary law as a special region and contained in Law No. 24 of 1956 concerning the Establishment of the Autonomous Region of Atjeh Province and Amendments to the Regulations on the Establishment of the Province of North Sumatra but this rebellion still occurs because in the law does not mention the granting of autonomy for Aceh based on Islamic law (Aspinall, 2007; Grayman, Delvecchio, 2009; Waizenegger \& Hyndman, 2010).

The rebellion occurred again in 1976 under Hasan Tiro by establishing GAM (Free Aceh Movement). The problem that triggered this rebellion was a very strong centralization policy in the Soeharto era which created social and economic injustice in Aceh (Miller, 2009). In handling this rebellion, several approaches have been conducted by the government including: the military approach (Soeharto), the welfare approach (Habibie), the dialogue approach (Abdurrahman Wahid, Megawati, and Susilo Bambang Yudhoyono) (Ananta, 2007; Ansori, 2012; Myrttinen, 2011). After the adoption of Law No. 11 of 2006 concerning the Government of Aceh, it is increasingly clear the status of Aceh is given special autonomy to resolve conflicts peacefully, thoroughly, and sustainably which in essence wants to rebuild Aceh's territory and people after the earthquake and tsunami disaster in Aceh.

Special autonomy in the law means that the Province of Aceh is a region that is given special authority to regulate and manage its own affairs of government and local communities and in creating an acceleration of economic growth, the Province of Aceh receives funds sourced from the APBN known as special autonomy funds that can be used to finance the construction and maintenance of infrastructure, empowering the people's economy, reducing poverty, as well as funding for education, social funding, and health (Aspinall, 2007; Feith, 2006; Nurhasim, 2009; Sindre, 2010; Zainal, 2017).

The Special Autonomy Funds can be determined as the source of revenue for Aceh and the district /city, however, the special autonomy fund is not directly transferred by the Central Government to the regional government, in this case, the district/city, but is first transferred to the revenue of the Provincial Government of Aceh. This is in accordance with the provisions of Article 183 paragraph (1) of the UUPA, namely, the special autonomy fund is the revenue of the Government of Aceh which is intended to finance development, especially the construction and maintenance of infrastructure, empowerment of the people's economy, poverty alleviation and funding for education, social and health, and in its implementation adjusted with conditions in the area (Undang-Undang Nomor 11 Tahun 2006 Tentang Pemerintahan Aceh, 2006).

The granting of special autonomy funds is basically the delegation of fiscal responsibility from the central government to regional governments which aims to create efficiency in the distribution of public sector budgets, one of which is reducing poverty (Mehmood, R., Sadiq, S., \& Khalid, 2010). Tiebout (1956) developed the theory of decentralization which states that with the decentralization of public goods, it allows for better public accountability, especially when 
faced with and fulfilling diverse individual preferences. And under fiscal decentralization, local governments play a role in providing public goods and the community will certainly side with the government that provides according to their preferences, in this case, Musgrave (1959) explains the important role of government through budget policies such as at the allocation, distribution and stabilization stages resource.

\section{CONCLUSION}

Conclusion One of the special autonomy funds provided by the government to the Province of Aceh is to catch up with Aceh due to the conflict and tsunami disaster that hit Aceh, particularly the problem of poverty which is still a priority of the Government of Aceh through various policy programs carried out. The findings of this study are: firstly, the budget sourced from the special autonomy funds has been designed to side with the poor and continues to increase every year 120 billion in 2008 to 439 billion in 2019 . However, in the implementation of programs and policies to reduce poverty is still in the form of false participation due to low transparency and accountability are still the result of stalled traffic and hampered all programs that have been formulated. Transparency, accountability, and participation are related to the availability of human resources who have limited capabilities.

Secondly, the cause of the slow process of poverty alleviation due to economic dependence with other regions outside of Aceh and the small number of medium and large industries in Aceh which results in no multifier effect from large special autonomy funds disbursed in the community. This can be seen from the money circulation in Aceh, which is mostly sourced from non-business government funds. Apart from the fact that other side factors such as differences in opinion in the process of evaluating the use of special autonomy funds to reduce poverty have created confusion between stakeholders involved and the community, it implies from various online reports circulating after BPS released the poverty rate in Aceh. Nationally, Aceh experienced a reduction in poverty, but in public sentiment generated by media sentiment, the reduction in poverty in Aceh is not in line with expectations after the granting of special autonomy funds.

\section{LIMITATION AND STUDY FORWARD}

The scope of the use of special autonomy funds is very broad since it is divided into several key sectors, including infrastructure, health, education, poverty reduction and the economic empowerment of the Community, which is the limitation of this report. This would be fascinating if future research concentrates on the use of special autonomy funds in poverty reduction programmes.

\section{ACKNOWLEDGEMENT}

I would like to thank the Indonesia Endowment Fund for Education (LPDP) and Universitas Teuku Umar for supporting the study.

\section{AUTHORS CONTRIBUTION}

The first author collected data and analysed data. All co-author contribute to the literature review and analysing data.

\section{REFERENCES}

1. Agrawal, P. (2005). Economic Growth and Poverty Reduction: Evidence From Kazakhstan. Asian Development Reviews, 34(2), 90-115.

2. Agusta, I. (2014). Diskursus, Kekuasaan, Dan Praktik Kemiskinan. Yayasan Pustaka Obor Indonesia.

3. Alcock. (1997). Understanding Poverty (Second). Palgrave. https://doi.org/10.1007/978-1-349-25666-2

4. Alfian. (1980). Kemiskinan Struktural. YIIS.

5. Amalia, A. (2015). Social Capital and Poverty. Sosio Informa, 1(3), 310-323.

6. Ananta, A. (2007). The Population and Conflicts. In Aceh: A New Dawn. (pp. 15-33). Institute of Southeast Asian Studies. https://doi.org/10.1355/9789812305749-007

7. Ansori, M. H. (2012). From Insurgency to Bureaucracy: Free Aceh Movement, Aceh Party and the New Face of Conflict. Stability: International Journal of Security \& Development, 1(1), 31-44. https://doi.org/10.5334/sta.ah

8. Appleford, Gabrielle, V. O. \& W. E. (2015). Pro-Poor Budget Analysis of Kenya's Free Primary Education Policy. Development in Practice, 25(4), 587-593. https://doi.org/10.1080/09614524.2015.1026879

9. Arifin, B. (2006). Pemikiran Untuk Mengeluarkan Petani Dari Kemiskinan. Jurnal Pangan, 15(1).

10. Arifin, T. (2006). Nelayan, Kemiskinan dan Pembangunan. Mesogene.

11. Arsyad, L. (2014). Ekonomi Pembangunan. STIE YKPN.

12. Asmorowati and Marcus. (2006). Urban Poverty and the Rural Development Bias: Some Notes from Indonesia. Journal of Developing Societies, 22(2), 145-168. https://doi.org/10.1177/0169796X06065800

13. Aspinall, E. (2007). The construction of grievance: Natural resources and identity in a separatist conflict. Journal of Conflict Resolution. https://doi.org/10.1177/0022002707307120

14. Baharoglu, D \& Kessides, C. (2001). Urban Poverty. In W. Bank, PRSP Sourcebook. World Bank.

15. Bappeda Aceh. (2019). Special Autonomy Funds.

16. BPS. (2014). Keadaan Kependudukan Provinsi Aceh Tahun 2014.

17. BPS. (2018). Persentase Penduduk Miskin Pada September. 
18. Brautigam, D. (2004). The People's Budget? Politics, Participation and Pro-poor Policy. Development Policy Review, 22(6), 653-668. https://doi.org/10.1111/j.1467-7679.2004.00270.x

19. Collier, Paul and Dollar, D. (2002). Aid allocation and poverty reduction. European Economic Review, 46(8), 1475-1500. https://doi.org/10.1016/S0014-2921(01)00187-8

20. Craswell, J. (2014). Penelitian Kualitatif \& Desain Riset: Memilih di Antara Lima Pendekatan. Pustaka Pelajar.

21. Dartanto, T. \& N. (2013). The Determinats of Poverty Dinamics in Indonesia: Evidence from Panel Data. Bulletin of Indonesian Economic Studies, 61(84). https://doi.org/10.1080/00074918.2013.772939

22. El Ibrahimy, M. N. (2001). Peranan Tgk Daud Beureu-eh Dalam Pergolakan Aceh. Media Da'wah.

23. Fallis, A. (2013). Qualitative Analysis Using NVivo. Journal of Chemical Information and Modeling, 5(3), 55-65. https://doi.org/10.1017/CBO9781107415324.004

24. Fan, G. (1998). Market-Oriented Economic Reform And The Growth Of Off-Budget Local Public Finance. In D. J. S. Brean (Ed.), Taxation in Modern China (pp. 209-227). Routledge Press.

25. Feith, P. (2006). The Aceh Peace Process: Nothing Less than Success. Defense.

26. Firdaussy, CM dan Tisdell, C. (1992). Determinant of Rural Income and Poverty at The VillageLevel in Bali, Indonesia. Malaysian Journal of Economic Studies, 29(1), 19-34.

27. Grayman, Delvecchio, and B. (2009). Conflict nightmares and trauma in Aceh. Culture, Medicine and Psychiatry. https://doi.org/10.1007/s11013-009-9132-8

28. Hadar, I. A. (2004). Utang, Kemiskinan dan Globalisasi : Pencarian Solusi Alternatif. Lapera Pustaka Utama.

29. Hagenaars, A. (1991). The Definition and Measurement of Poverty. In L. O. (Ed.), Economic Inequality and Poverty: International Perspective. M.E. Sharpe.

30. Harris, B. \& W. (2005). Poverty and Capitalism. QEH Working Paper Series, 13(4), 1-14.

31. Hong, H. \& A. (2009). Government Spending on Public Goods: Evidence on Growth and Poverty. Economic and Political Weekly, 44(31), 102-108.

32. Huraerah, A. (2013). Strategi Kebijakan Penanggulangan Kemiskinan di Indonesia. Jurnal Ilmu Kesejahteraan Sosial, 12(1), 3-13.

33. Jonadi, A. (2002). Analisis Pertumbuhan Ekonomi dan Kemiskinan di Indonesia. Jurnal Kajian Ekonomi, $1(1), 140-164$.

34. Jung, H., and E. T. (2003). The Impact of Public Education Expenditure on Human Capital, Growth, and Poverty in Tanzania and Zambia: a General Equilibrium Approach. Journal of Policy Modeling, 25(1), 701725. https://doi.org/10.1016/S0161-8938(03)00060-7

35. Kamarni, N. (2012). Analisis Modal Sosial Sebagai Salah Satu Upaya Dalam Pengentasan Kemiskinan (Studi Kasus: Rumah TanggaMiskin di Kecamatan Koto Tangah Kota Padang. Jurnal Manajemen Dan Kewirusahaan, 3(3), 36-52.

36. Kemenkopmk. (2014). Target dan Capaian Persentase Pneduduk Miskin. Retrieved from Target dan Capaian Penduduk Miskin.

37. Kuncoro. (2002). Dasar-Dasar Analisis Kemiskinan. Grapindo Persada.

38. Kuncoro, A. (2006). Corruption and Business Uncertanty in Indonesia: Riding Along a Bumpy Road Indonesian Economy in an Emerging Democratic Era. ASEAN Economic Bulletin, 23(1), 11-34. https://doi.org/10.1355/AE23-1B

39. Kwadzo, M. (2010). Conceptualization and Measurement of Poverty: A Comparative Analysis. University of Pennsylvania.

40. Mehmood, R., Sadiq, S., \& Khalid, M. (2010). Impact of Fiscal Decentralisation on Human Development: A Case Study of Pakistan. The Pakistan Development Review, 2(1), 513-530. https://doi.org/10.30541/v49i4IIpp.513-530

41. Miller, M. . (2009). Rebellion and Reform in Indonesia: Jakarta's Security and Autonomy Policies in Aceh. Routledge. https://doi.org/10.4324/9780203888193

42. Mundra, S. (2019). A REVIEW OF INDIAN GOVERNMENT INCLUSIVE INITIATIVES: POVERTY ON THE DECLINE. Humanities \& Social Sciences Reviews, 7(1), 324-331. https://doi.org/10.18510/hssr.2019.7137

43. Musgrave, A. R. (1959). The Theory of Public Finance. McGraw-Hill. https://doi.org/10.1007/978-1-34923426-4

44. Myrttinen, H. (2011). Guerrillas, Gangsters and Contractors: Integrating Former Combatants and Its Impact on SSR and Development in Post-conflict Societies. In Back to The Root: Security Reform and Development. DCAF.

45. Nation, U. (2008). Global Issues.

46. Nurhasim, M. (2009). Transformasi Politik Gerakan Aceh Merdeka. Jurnal Penelitian Politik, 6(1).

47. Okezone. (2018). Dana Otsus Rp56 Triliun Lebih, Kemiskinan di Aceh Justru Meningkat.

48. Undang-Undang Nomor 11 Tahun 2006 Tentang Pemerintahan Aceh, (2006).

49. Prayitno, H. dan L. A. (1987). Petani Desa dan Kemiskinan. BPFE.

50. Rahardjo, D. (2006). Kemiskinan: Menggali Pengalaman Pembangunan dalam Menuju Indonesia Sejahtera. Pustaka LP3ES Indonesia. 
51. Ravallion, M. (2001). Growth, Inequality and Poverty: Looking Beyond Averages. Word Development Journal, 29(11), 1803-1815. https://doi.org/10.1016/S0305-750X(01)00072-9

52. Roberts, J. (2003). Poverty reduction outcomes in education and health public expenditure and aid.

53. Robinson, M. (2006). Budget analysis and policy advocacy: the role of non-governmental public action.

54. Samson, M. (2009). Social cash transfers and pro-poor growth.

55. Sanogo, T. (2019). Does Fiscal Decentralization Enhance Citizens' Access to Public Services and Reduce Poverty? Evidence from Côte d'Ivoire Municipalities in a Conflict Setting. World Development, 113(1), 204221. https://doi.org/10.1016/j.worlddev.2018.09.008

56. Schneider, A. (2009). Pro-Poor Governance and Policy Process : A Framework.

57. Sen, A. (1976). Poverty: an Ordinal Approach to Measurement. Economitrica, 44(1), $219-231$. https://doi.org/10.2307/1912718

58. Serambinews. (2018). Ini Total Dana Otsus yang Telah Diterima Aceh Sejak Tahun 2008.

59. Shepherd, A. (2017). Chronic Poverty: Some Policy Implications. Development, 50(2), 48-55. https://doi.org/10.1057/palgrave.development.1100381

60. Siahaan, H. (2011). Profik Kemiskinan di Surabaya: Sebuah Analisis Fenomenologis.

61. Simson, R. (2012). Following the money: Examining the evidence on 'pro-poor' budgeting.

62. Sindre, G. M. (2010). From Political Exclusion to Inclusion: GAM, The Political Transformation of. In PCD Press (Ed.), Aceh The Role of Democracy for Peace and Reconstruction (pp. 215-256).

63. Suparlan, P. (1984). Kemiskinan di Perkotaan. Sinar Harapan.

64. Swastika, Dewa KS., Supriyatna, Y. (2008). The Characteristics of Poverty and Its Alleviation in Indonesia. Forum Penelitian Agro Ekonomi, 26(2), 103-115. https://doi.org/10.21082/fae.v26n2.2008.103-115

65. Tarlton, C. D. (1965). Symmetry and Asymmetry as Elements of Federalism. Journal of Politics, 27(4), 861874. https://doi.org/10.2307/2128123

66. Tiebout, C. M. (1956). A Pure Theory of Local Expenditures. Journal of Political Economy, 64(1), 416-424. https://doi.org/10.1086/257839

67. Vandemoorele, J. (2003). The MDGs and Pro-Poor Policies: Can External Partners Make A Difference? UNDP.

68. Wagle, U. (2002). Rethingking Poverty: Definition and Measurement. International Social Science Journal, 21(1), 155-165. https://doi.org/10.1111/1468-2451.00366

69. Waidl, et all. (2008). Mendahulakan si Miskin : Buku Sumber bagi Anggaran Pro-Rakyat. LKiS.

70. Waizenegger, A., \& Hyndman, J. (2010). Two solitudes: Post-tsunami and post-conflict Aceh. Disasters. https://doi.org/10.1111/j.1467-7717.2010.01169.x

71. Winardi. (2010). Ekonomi Pembangunan. Gramedia.

72. Yunus, S., Zainal, S., Jalil, F., \& Maya Aprita Sari, C. (2020). CORRELATION OF SOCIAL CAPITAL AND POVERTY FARMERS IN ACEH. Humanities \& Social Sciences Reviews, 8(1), 20-26. https://doi.org/10.18510/hssr.2020.813

73. Zainal, S. (2017). Transformasi Konflik Aceh dan Relasi Sosial-Politik di Era Desentralisasi. MASYARAKAT: Jurnal Sosiologi. https://doi.org/10.7454/mjs.v21i1.4757 